\title{
Estimating Cardiovascular Health Gains From Eradicating Indoor Cold in Australia
}

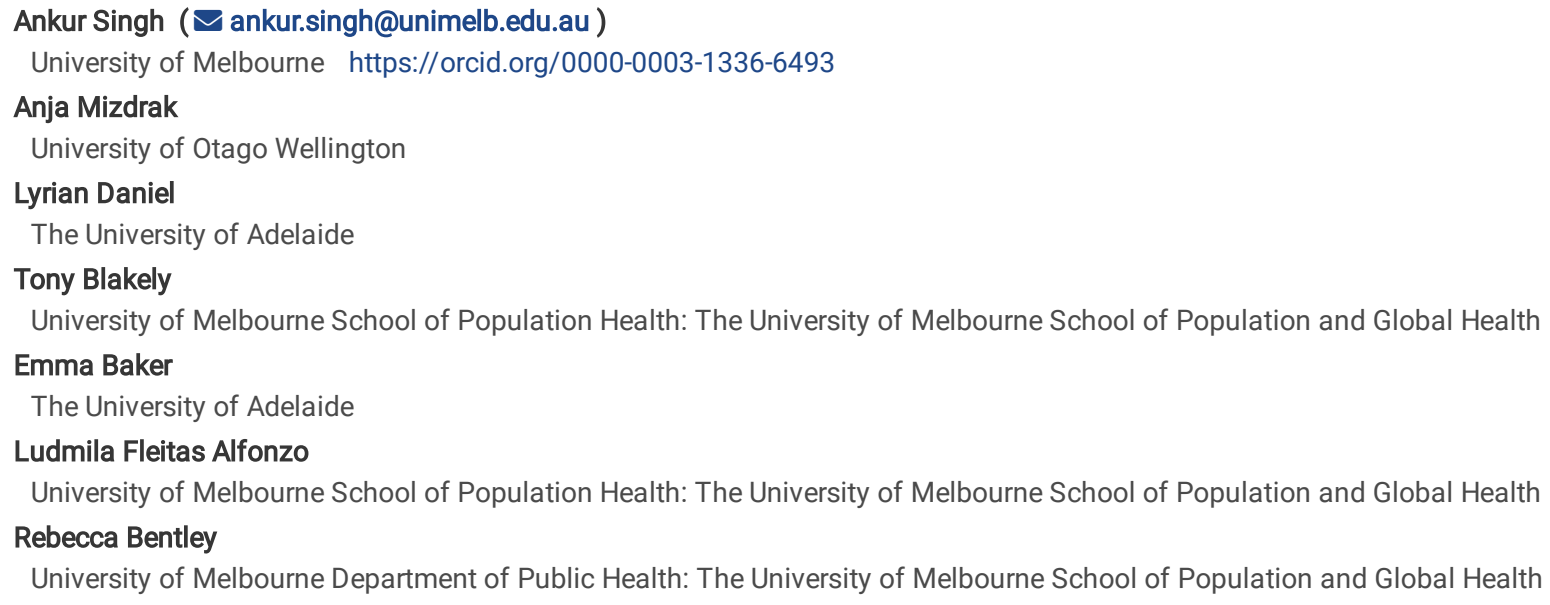

\section{Research Article}

Keywords: Cardiovascular disease, CVD, indoor cold, policy simulation

Posted Date: December 28th, 2021

DOI: https://doi.org/10.21203/rs.3.rs-1193818/v1

License: (9) (1) This work is licensed under a Creative Commons Attribution 4.0 International License. Read Full License 


\section{Abstract \\ Background}

Exposure to cold indoor temperature ( $<18$ degrees Celsius) increases cardiovascular disease (CVD) risk and has been identified by the WHO as a source of unhealthy housing. While warming homes has the potential to reduce CVD risk, the reduction in disease burden is not known. We simulated the population health gains from reduced CVD burden if all homes in Australia were adequately warm.

\section{Methods}

The health effect of eradicating cold housing through reductions in CVD was simulated using proportional multistate lifetable model. The model sourced CVD burden and epidemiological data from Australian and Global Burden of Disease studies. The prevalence of cold housing in Australia was estimated from the Australian Housing Conditions Survey. The effect of cold indoor temperature on blood pressure (and in turn stroke and coronary heart disease) was estimated from published research.

\section{Results}

Eradication of exposure to indoor cold could achieve a gain of undiscounted one and a half weeks of additional health life per person alive in 2016 (baseyear) in cold housing through CVD alone. This equates to 0.447 (uncertainty interval: $0.064,1.34 ; 3 \%$ discount rate) HALYs per 1,000 persons over remainder of their lives through CVD reduction. One-fifth of the total health gains are achievable between 2016 and 2035 . Although seemingly modest, the gains outperform currently recommended CVD interventions including dietary advice for adults ( 0.017 per 1000 people, Ul: $0.01,0.027)$, lifestyle program for adults $(0.024$, Ul: $0.01,0.027)$ and Community Heart Health Program $(0.141, \mathrm{Ul}: 0.071,0.221)$.

\section{Conclusion}

Cardiovascular health gains achievable through eradication of cold housing are comparable with lifestyle and dietary interventions. The benefits of housing improvement are also substantial in other social domains (comfort, heating bills and energy efficiency).

\section{Introduction}

The World Health Organisation (WHO) Housing and Health guidelines make a strong recommendation that indoor temperatures should be above $18^{\circ} \mathrm{C}$ to protect residents from the harmful health effects of cold indoor environments (1). Recent work suggests that many homes, even in the relatively mild or temperate climates of Australia, do not meet this standard $(2,3)$. Cold indoor temperature is associated with elevated blood pressure and randomised controlled trials (RCTs) have shown that interventions reducing exposure to cold indoor temperatures reduce systolic blood pressure $(4,5)$. Observational studies, from the UK and 16 middle to high income countries also report consistent findings and confirm an association between low temperature and increased systolic blood pressure (6-8). This means that intervening to improve the indoor temperature control should reduce cardiovascular disease incidence and prevalence.

Reducing exposure to unhealthy indoor temperature is achievable through interventions such as insulation, weatherization (draft-sealing), efficient heating/cooling appliances, cheaper fuel alternatives (solar panels), and subsidies and market-based initiatives (1). Generating standardised estimates of the health gains from housing-focussed interventions such as these allows for direct comparison of their utility with other more commonly used public health leavers (e.g. tobacco control, pharmaceuticals). This paper aims to estimate the total potential cardiovascular health gains from a hypothetical 'magic wand' intervention that lifts all cold housing to an average of 20 degree Celsius (i.e., the average temperature in indoor spaces in the home during waking hours), in the six colder months of the year.

Health gains from prevention occur many years into the future, requiring simulation modelling that quantifies health gain using summary measures such as health adjusted life years (HALYs). By using a measure such as a HALY, one can also compare the health impacts of otherwise disparate interventions (9, 10).

We used simulation modelling to quantify the health gain through a reduction in cardiovascular disease that could be achieved if exposure to indoor cold was hypothetically eliminated in three states of Australia (11). Using an existing league table of preventive interventions for Australia and New Zealand (12), we examine the relative population health gains of hypothetical eradication of indoor cold with other actual prevention interventions.

\section{Methods}

\section{Intervention conceptualisation}

We based our estimate of the effect of cold housing on cardio-vascular disease burden on two sources of evidence. First, the negative effect of cold indoor temperature on blood pressure $(4,5)$. Second, the effect of hightened blood pressure on cardiovascular disease risk (specifically ischemic heart disease and ischemic and haemorrhagic stroke) (13) (see supplementary file 1). Cardiovascular disease responds rapidly to change in risk factors; therefore, we assume little to no time lag in response to temperature change. 


\section{Model overview}

We used a proportional multistate lifetable (pMSLT) simulation model to estimate health gains achievable through interventions on exposure to cold indoor temperature within a specified population (11). We simulated the 2016 Australian population through to 2126 (maximum potential lifetime of the living cohort in 2016 being set to 110 year of age) in annual time steps with transition probabilities for all-cause mortality, and incidence and case fatality rates of cardiovascular diseases in subsidiary lifetables. This model was applied once for Business as Usual (BAU), based on the current prevalence of cold housing (prevalence assumed unchanging into the future), and then for the intervention (hypothetical elimination of cold housing) by altering the CVD incidence rates given the shift in population average blood pressure. The two components of the model are linked by population impact fractions (PIFs), that summarise the proportion reduction in diseases associated with change in indoor temperature exposure for cohorts defined by age and sex.

We modelled relevant cardiovascular diseases (heart disease and stroke) as independent of each other in parallel lifetables. Estimated changes in morbidity and mortality rates were summed together in an overall lifetable at each annual cycle, adding the health gain (Intervention minus BAU) across the diseases and years. The 'health adjustment' to convert life years gained to HALYs gained was achieved by subtracting off each life year gained the proportion 'lost' due to morbidity, using years of life lived with disability (YLDs) from burden of disease studies divided by the population in each sex by age-group as a measure of proportionate morbidity.

\section{Input parameters}

We have presented data inputs with their sources in Table 1. 
Table 1

Key data Inputs

\begin{tabular}{|c|c|c|c|}
\hline Parameter & Data Source & Comments/ notes/ model and data assumptions & Value \\
\hline \multirow{4}{*}{$\begin{array}{l}\text { Unhealthy } \\
\text { indoor } \\
\text { temperature } \\
\text { prevalence } \\
\text { at base } \\
\text { year } 2016\end{array}$} & \multirow[t]{4}{*}{$\mathrm{AHCD}$} & \multirow{3}{*}{$\begin{array}{l}\text { Prevalence of people experiencing indoor cold temperature was obtained from the Australian Housing } \\
\text { Conditions Dataset (AHCD) (14). The AHCD survey asked participants 'Are you able to warm your house } \\
\text { during winters'? Those responding 'Yes' were considered as experiencing indoor cold temperature. We } \\
\text { accounted for age variations in the prevalence as estimated from the AHCD. }\end{array}$} & \multirow{4}{*}{$\begin{array}{l}5.74 \% \\
\text { (Refer to } \\
\text { Table } 2 \text { for } \\
\text { age } \\
\text { variations) }\end{array}$} \\
\hline & & & \\
\hline & & & \\
\hline & & $\begin{array}{l}\text { Uncertainty. Double of standard errors in age-specific prevalence obtained from AHCD with correlation of } \\
1 .\end{array}$ & \\
\hline \multirow{2}{*}{$\begin{array}{l}\text { Average } \\
\text { temperature } \\
\text { in cold } \\
\text { houses }\end{array}$} & & \multirow{2}{*}{\multicolumn{2}{|c|}{ Average outdoor temperatures: Victoria $\left(15.04^{\circ} \mathrm{C}\right)$, New South Wales $\left(18.43^{\circ} \mathrm{C}\right)$, South Australia $\left(20.19^{\circ} \mathrm{C}\right)$}} \\
\hline & & & \\
\hline $\begin{array}{l}\text { All-cause } \\
\text { mortality } \\
\text { rates }\end{array}$ & GBD & $\begin{array}{l}\text { Data on all-cause mortality rates by sex and age group for } 2016 \text { were obtained from the Global Burden of } \\
\text { disease results tool and inputted directly (27). }\end{array}$ & $\begin{array}{l}\text { Refer to } \\
\text { Table } 2 \text { for } \\
\text { age and } \\
\text { sex } \\
\text { variations }\end{array}$ \\
\hline $\begin{array}{l}\text { All-cause } \\
\text { morbidity } \\
\text { rates }\end{array}$ & GBD & $\begin{array}{l}\text { Data on years of life lived with disability (YLD) were obtained from the Global Burden of Disease study for } \\
\text { each sex and age group in } 2016 \text {. No time trend was allowed, as YLD rates by age in the GBD have not } \\
\text { changed much over time. Morbidity rates were directly inputted in the main life table to estimate HALYs } \\
\text { (27). }\end{array}$ & $\begin{array}{l}\text { Refer to } \\
\text { Table } 2 \text { for } \\
\text { age and } \\
\text { sex } \\
\text { variations }\end{array}$ \\
\hline \multirow[t]{3}{*}{$\begin{array}{l}\text { Disease } \\
\text { specific } \\
\text { incidence, } \\
\text { prevalence } \\
\text { and case } \\
\text { fatality } \\
\text { rates }\end{array}$} & \multirow[t]{3}{*}{ GBD } & $\begin{array}{l}\text { We applied national disease-specific estimates from GBD (27) to the population of three states New South } \\
\text { Wales, Victoria and South Australia. Comparison of disease specific morbidity across the three states and } \\
\text { national estimates showed a maximum of } 10 \% \text { difference - therefore we applied Australian disease data } \\
\text { to these three states. The disease-specific incidence rates, prevalence and mortality rates, and case } \\
\text { fatality rates (mortality rate divided by prevalence) for ischemic heart disease and stroke were obtained } \\
\text { from the GBD data (27). Stroke includes ischemic stroke and haemorrhagic stroke (subarachnoid and } \\
\text { intracerebral). Disease specific rates for subarachnoid and intracerebral haemorrhagic stroke were } \\
\text { summed and the ratio to ischemic stroke was included in the model for uncertainty analysis. All disease- } \\
\text { specific epidemiological inputs were processed through DISMOD II and used to ensure coherence and } \\
\text { smoothing for age (28). }\end{array}$ & \multirow[t]{3}{*}{$\begin{array}{l}\text { Refer to } \\
\text { Table } 2 \text { for } \\
\text { age and } \\
\text { sex } \\
\text { variations }\end{array}$} \\
\hline & & $\begin{array}{l}\text { Annual Percentage Changes: the annual percentage changes were estimated using Poisson regression on } \\
\text { incidence rates and case fatality rates from } 1990 \text { to } 2016 \text { GBD data and included as inputs to the PMSLT. }\end{array}$ & \\
\hline & & $\begin{array}{l}\text { Uncertainty: +/- } 5 \% \text { SD (log normal distribution for incidence), correlations } 1.0 \text { between sexes for all } \\
\text { disease. }\end{array}$ & \\
\hline \multirow[t]{2}{*}{$\begin{array}{l}\text { Disease } \\
\text { specific } \\
\text { morbidity }\end{array}$} & \multirow[t]{2}{*}{ IHME/GBD } & \multicolumn{2}{|l|}{$\begin{array}{l}\text { The sex and age specific disability rates were calculated as disease's YLD obtained from GBD (27)divided } \\
\text { by the number of prevalent cases. }\end{array}$} \\
\hline & & \multicolumn{2}{|l|}{ Uncertainty: $+/-10 \%$ SD } \\
\hline \multirow{3}{*}{$\begin{array}{l}\text { Relative risk } \\
\text { from indoor } \\
\text { cold to } \\
\text { systolic } \\
\text { blood } \\
\text { pressure }\end{array}$} & \multirow[t]{3}{*}{$\begin{array}{l}\text { Review of } \\
\text { relative risks } \\
\text { as part of } \\
\text { the project }\end{array}$} & \multirow{2}{*}{$\begin{array}{l}\text { Using evidence and search terms from the WHO Housing and Health Guidelines, we reviewed the health } \\
\text { effects of exposure to indoor cold. Our review found consistent evidence for the effect of indoor cold on } \\
\text { hypertension. We performed risk of bias assessment using ROBINS-E and ROB tools on interventional and } \\
\text { observational studies on the relationship between indoor cold and systolic blood pressure. Two studies } \\
\text { (one cohort (7) and one randomised controlled trial(4)) were found to have low to moderate risk of bias. } \\
\text { Relative risk from the randomised controlled trial was used. }\end{array}$} & $\begin{array}{l}5.8 \mathrm{mmHg} \\
(95 \% \mathrm{Cl} \\
-9.3,-2.4))\end{array}$ \\
\hline & & & \multirow{2}{*}{$\begin{array}{l}\text { More } \\
\text { detailed } \\
\text { review } \\
\text { results } \\
\text { presented } \\
\text { in Table } 1 \\
\text { in } \\
\text { Appendices }\end{array}$} \\
\hline & & Uncertainty: As provided by Saeki, Obayashi (4) & \\
\hline \multirow[t]{2}{*}{$\begin{array}{l}\text { Systolic } \\
\text { blood } \\
\text { pressure } \\
\text { distribution }\end{array}$} & ABS & $\begin{array}{l}\text { Data on systolic blood pressure by age and sex was obtained from the National Health Survey 2017-18 } \\
\text { from the Australian Bureau of Statistics (ABS) (29). Mean and standard deviations of systolic blood } \\
\text { pressure were included as input to the pMSLT simulation model. }\end{array}$ & \multirow{2}{*}{$\begin{array}{l}\text { Refer to } \\
\text { Table } 4 \text { in } \\
\text { Appendices } \\
\text { for age and } \\
\text { sex } \\
\text { variations }\end{array}$} \\
\hline & & Uncertainty: As provided by the National Health Survey (29) & \\
\hline $\begin{array}{l}\text { Relative risk } \\
\text { from } \\
\text { systolic } \\
\text { blood } \\
\text { pressure to } \\
\text { ischemic } \\
\text { heart } \\
\text { disease and } \\
\text { stroke }\end{array}$ & $\begin{array}{l}\text { Forouzanfar, } \\
\text { Liu (18) }\end{array}$ & $\begin{array}{l}\text { Rate ratios for systolic blood pressure to ischemic heart disease, ischemic stroke and haemorrhagic stroke } \\
\text { were taken from IHME GBD (27). } \\
\text { Uncertainty: As provided by Forouzanfar, Liu (18) }\end{array}$ & $\begin{array}{l}\text { Refer to } \\
\text { Table } 5 \text { in } \\
\text { Appendices } \\
\text { for age } \\
\text { variations }\end{array}$ \\
\hline
\end{tabular}


Estimates of the number of people exposed to inadequate indoor temperature by age and sex was obtained from the Australian Housing Conditions Dataset survey $(14,15)$ and assumed to be constant into the future. Data on the age and sex distribution of the Australian population was obtained from the Australian Population Census 2016. Disease-specific incidence, prevalence and case fatality rates were obtained from IHME Global Burden of Disease for Australia. We checked for coherence between epidemiological parameters derived from this array of data sources (i.e., incidence, case fatality and prevalence) for each disease by examining plotted trends and further processed them through epidemiological tool DISMOD II to use as data inputs (16).

\section{Intervention specification}

The relative risk of high blood pressure from exposure to indoor cold was estimated from a randomised controlled trial (4). This study reported a difference of $5.8 \mathrm{mmHg}(95 \% \mathrm{Cl}(-9.3,-2.4))$ between an intervention group, who occupied a room heated to $22^{\circ} \mathrm{C}$, and the control group who occupied a room kept stable at $12^{\circ} \mathrm{C}$. Both groups were given sufficient clothing and bedclothes to be warm. Both groups were exposed to the respective interventions for 11 hours during the night and blood pressure was measured in 15 minutes intervals at night time and in the morning after rising. The $5.8 \mathrm{mmHg}$ difference was that when awake (as there was no difference when awake due to compensation using more bedding in the experimentally colder group). This effect estimate was converted into an absolute change achievable in systolic blood pressure per $1^{\circ} \mathrm{C}$ temperature increase.

Data on the prevalence of people experiencing indoor cold was obtained from the Australian Housing Conditions Dataset that representatively sampled housing from 4,500 households' condition across three Australian States (Victoria, New South Wales and South Australia) (14). The measure comprised a self-reported assessment of ability to keep warm indoors at home during cold winter weather. The average outdoor temperature for Victoria in 2016 was $15.0^{\circ} \mathrm{C}$, for New South Wales was $18.4^{\circ} \mathrm{C}$ and for South Australia was $20.2^{\circ} \mathrm{C}(17)$. To account for seasonal variations in temperature and time spent outside homes we assumed that our simulated population is exposed to indoor cold ranging from one-third (the awake 2/3rds of the day for the colder half of the year for those people at home most of the day) to one-sixth (same logic, but for people working or out of the home for approximately half of waking hours) of the time. A beta distribution for uncertainty in the intervention effect estimate was applied to account for variability in this exposure time. To simulate the effect of indoor cold on blood pressure we estimated the difference between cold houses (average temperature of $16^{\circ} \mathrm{C}$ ) and adequately warmed houses (average temperature of $20^{\circ} \mathrm{C}$ ). Assuming a short latency of cold to blood pressure, the change in average blood pressure of the year was calculated within each iteration of the simulation as: this proportion of the year exposed ranging from 1/6 to 1/3; multiplied by the difference in temperature (4 degrees, by lifting average cold housing from 16 to 20 degrees); multiplied by the RCT-based estimate of change in systolic blood pressure per 1 degree celsius.

Relative risks for the causal relationship between systolic blood pressure and ischemic heart disease, ischemic stroke and haemorrhagic stroke were obtained from the Global Burden of Disease (GBD) study (18) (see supplementary Table 5). The intervention was simulated on the 2016 population for the same jurisdictions covered by the Australian Housing Conditions datasets (i.e., Victoria, New South Wales and South Australia). The intervention (eradication of cold housing) was modelled as lifelong. BAU exposure to cold housing was based on exposures in 2016 for cohorts defined by age-group and sex.

\section{Analyses}

Probabilistic uncertainty analyses using a Monte Carlo simulation method was conducted on input parameters (see Table 1). More generous uncertainty was applied where we were less confident on input parameter (for example the subjective measurement of indoor cold in Australia). Simulations were run using the ERSATZ add in to Excel with 2000 iterations used to generate $95 \%$ uncertainty intervals (UI) for the HALY estimates.

Our outputs included HALYs gained by indoor cold eradication within a life-time and ten- and -twenty-year time horizons. Outcomes were reported both with $0 \%$ and $3 \%$ discount rates and also per 1000 persons.

We compared the estimated HALYs gained from cold housing eradication with other CVD-related interventions described in interactive league tables (12).

\section{Results}

Nearly $6 \%$ of the population were estimated to experience cold housing. Younger people reported a higher prevalence of indoor cold exposure ( $9 \%$ under the age of 30 years) compared to older ages (3.4\% over the age of 75 years) (Table 2$)$. 
Table 2

Input data for starting cohort in 2016

\begin{tabular}{|c|c|c|c|c|c|c|c|c|c|c|c|c|c|c|}
\hline \multirow[t]{2}{*}{$\begin{array}{l}\text { Age } \\
\text { group }\end{array}$} & \multirow[t]{2}{*}{$n$} & \multirow{2}{*}{$\begin{array}{l}\begin{array}{l}\text { Indoor } \\
\text { cold }\end{array} \\
\begin{array}{l}\text { Prevalence } \\
(\%)\end{array}\end{array}$} & \multicolumn{2}{|l|}{$\begin{array}{l}\text { All } \\
\text { cause }\end{array}$} & \multirow{2}{*}{$\begin{array}{l}\text { Systolic } \\
\text { BP } \\
\begin{array}{l}\text { Mean } \\
(S D)\end{array}\end{array}$} & \multicolumn{3}{|c|}{$\begin{array}{l}\text { Ischemic heart } \\
\text { disease }\end{array}$} & \multicolumn{3}{|l|}{$\begin{array}{l}\text { Ischemic } \\
\text { Stroke }\end{array}$} & \multicolumn{3}{|c|}{$\begin{array}{l}\text { Hemorthagic } \\
\text { Stroke }\end{array}$} \\
\hline & & & $\begin{array}{l}\text { Mortality } \\
\text { rate }\end{array}$ & $\begin{array}{l}\text { Morbiity } \\
\text { (proportion } \\
\text { reduction } \\
\text { in life year } \\
\text { for HALY) }\end{array}$ & & IR & CFR & DR & Incidence & CFR & DR & IR & CFR & DR \\
\hline \multicolumn{15}{|l|}{ Males } \\
\hline $0-4$ & 514007 & 8.98 & 18 & 0.032 & & 0 & 0.000 & 0 & 5 & 0.000 & 23 & 2 & 0.001 & 0 \\
\hline $5-9$ & 500318 & 8.98 & 9 & 0.039 & & 0 & 0.000 & 0 & 5 & 0.001 & 52 & 2 & 0.002 & 0 \\
\hline $10-14$ & 462301 & 8.98 & 11 & 0.056 & & 0 & 0.000 & 0 & 5 & 0.003 & 81 & 2 & 0.003 & 0 \\
\hline $15-19$ & 478494 & 8.98 & 42 & 0.082 & $\begin{array}{l}119.5 \\
(23.7)\end{array}$ & 1 & 0.002 & 0 & 5 & 0.004 & 110 & 2 & 0.005 & 0 \\
\hline $20-24$ & 552493 & 8.98 & 64 & 0.098 & $\begin{array}{l}119.5 \\
(23.7)\end{array}$ & 2 & 0.011 & 2 & 6 & 0.005 & 143 & 3 & 0.007 & 0 \\
\hline $25-29$ & 578722 & 8.98 & 75 & 0.107 & $\begin{array}{l}120.3 \\
(16.9)\end{array}$ & 5 & 0.017 & 3 & 8 & 0.005 & 191 & 5 & 0.009 & 0 \\
\hline $30-34$ & 571793 & 8.98 & 93 & 0.114 & $\begin{array}{l}120.3 \\
(16.9)\end{array}$ & 15 & 0.024 & 5 & 14 & 0.007 & 266 & 8 & 0.012 & 1 \\
\hline $35-39$ & 516034 & 7.49 & 118 & 0.121 & $\begin{array}{l}121.3 \\
(16.0)\end{array}$ & 38 & 0.028 & 10 & 24 & 0.008 & 383 & 13 & 0.015 & 2 \\
\hline $40-44$ & 512660 & 7.49 & 169 & 0.127 & $\begin{array}{l}121.3 \\
(16.0)\end{array}$ & 86 & 0.027 & 20 & 39 & 0.009 & 573 & 20 & 0.017 & 3 \\
\hline $45-49$ & 499837 & 7.49 & 237 & 0.134 & $\begin{array}{l}126.5 \\
(15.6)\end{array}$ & 177 & 0.024 & 38 & 60 & 0.009 & 885 & 28 & 0.019 & 5 \\
\hline $50-54$ & 486978 & 7.49 & 354 & 0.145 & $\begin{array}{l}126.5 \\
(15.6)\end{array}$ & 312 & 0.021 & 63 & 90 & 0.009 & 1323 & 37 & 0.022 & 8 \\
\hline $55-59$ & 465154 & 5.52 & 535 & 0.159 & $\begin{array}{l}132.4 \\
(18.5)\end{array}$ & 486 & 0.018 & 97 & 134 & 0.010 & 1949 & 48 & 0.027 & 12 \\
\hline $60-64$ & 411857 & 5.52 & 800 & 0.177 & $\begin{array}{l}132.4 \\
(18.5)\end{array}$ & 721 & 0.017 & 154 & 200 & 0.011 & 2775 & 62 & 0.037 & 19 \\
\hline $65-69$ & 377806 & 5.52 & 1227 & 0.201 & $\begin{array}{l}134.9 \\
(16.3)\end{array}$ & 1001 & 0.017 & 255 & 286 & 0.014 & 3874 & 81 & 0.060 & 30 \\
\hline $70-74$ & 331006 & 5.52 & 2018 & 0.230 & $\begin{array}{l}134.9 \\
(16.3)\end{array}$ & 1310 & 0.018 & 376 & 386 & 0.018 & 5774 & 105 & 0.107 & 50 \\
\hline $75-79$ & 205258 & 3.40 & 3462 & 0.260 & $\begin{array}{l}136.5 \\
(16.0)\end{array}$ & 1696 & 0.023 & 501 & 518 & 0.026 & 8841 & 145 & 0.224 & 95 \\
\hline $80-84$ & 137498 & 3.40 & 6308 & 0.297 & $\begin{array}{l}136.5 \\
(16.0)\end{array}$ & 2245 & 0.035 & 649 & 727 & 0.043 & 12677 & 217 & 0.429 & 178 \\
\hline $85-89$ & 84731 & 3.40 & 11646 & 0.342 & $\begin{array}{l}140.2 \\
(15.7)\end{array}$ & 3096 & 0.066 & 770 & 1119 & 0.076 & 16667 & 350 & 0.720 & 331 \\
\hline $90-94$ & 32443 & 3.40 & 18487 & 0.388 & $\begin{array}{l}140.2 \\
(15.7)\end{array}$ & 4561 & 0.151 & 817 & 1687 & 0.139 & 19947 & 536 & 1.085 & 533 \\
\hline $95-99$ & 6255 & 3.40 & 30624 & 0.429 & $\begin{array}{l}140.2 \\
(15.7)\end{array}$ & 5678 & 0.224 & 813 & 2077 & 0.187 & 22295 & 623 & 1.254 & 622 \\
\hline $100-104$ & 590 & 3.40 & 30624 & 0.429 & $\begin{array}{l}140.2 \\
(15.7)\end{array}$ & 5678 & 0.224 & 813 & 2077 & 0.187 & 22295 & 623 & 1.254 & 622 \\
\hline \multicolumn{15}{|l|}{ Females } \\
\hline $0-4$ & 486858 & 8.98 & 15 & 0.028 & & 0 & 0.000 & 0 & 6 & 0.000 & 37 & 3 & 0.002 & 0 \\
\hline $5-9$ & 475040 & 8.98 & 8 & 0.038 & & 0 & 0.000 & 0 & 6 & 0.000 & 85 & 3 & 0.002 & 0 \\
\hline $10-14$ & 437256 & 8.98 & 9 & 0.058 & & 0 & 0.000 & 0 & 5 & 0.002 & 129 & 3 & 0.002 & 0 \\
\hline
\end{tabular}

IR: Incidence Rate; CFR: Case Fatality Rate; DR: Disability rate.

IR, DR and Mortality rate presented per 100,000 persons and CFR per person 


\begin{tabular}{|c|c|c|c|c|c|c|c|c|c|c|c|c|c|c|}
\hline \multirow{2}{*}{$\begin{array}{l}\begin{array}{l}\text { Age } \\
\text { group }\end{array} \\
15-19\end{array}$} & \multirow{2}{*}{$\begin{array}{l}\text { n } \\
455281\end{array}$} & \multirow{2}{*}{$\begin{array}{l}\begin{array}{l}\text { Indoor } \\
\text { cold }\end{array} \\
8.98\end{array}$} & \multicolumn{2}{|l|}{$\begin{array}{l}\text { All } \\
\text { cause }\end{array}$} & \multirow{2}{*}{$\begin{array}{l}\text { Systolic } \\
\text { BP } \\
107.6 \\
(16.5)\end{array}$} & \multicolumn{3}{|c|}{$\begin{array}{l}\text { Ischemic heart } \\
\text { disease }\end{array}$} & \multicolumn{3}{|l|}{$\begin{array}{l}\text { Ischemic } \\
\text { Stroke }\end{array}$} & \multicolumn{3}{|c|}{$\begin{array}{l}\text { Hemonhagic } \\
\text { Stroke }\end{array}$} \\
\hline & & & 23 & 0.096 & & 1 & 0.001 & 0 & 5 & 0.004 & 171 & 3 & 0.003 & 0 \\
\hline $20-24$ & 528234 & 8.98 & 23 & 0.117 & $\begin{array}{l}107.6 \\
(16.5)\end{array}$ & 1 & 0.004 & 1 & 7 & 0.004 & 219 & 4 & 0.003 & 0 \\
\hline $25-29$ & 579388 & 8.98 & 29 & 0.125 & $\begin{array}{l}108.5 \\
(17.1)\end{array}$ & 2 & 0.006 & 3 & 10 & 0.003 & 293 & 6 & 0.005 & 0 \\
\hline $30-34$ & 580157 & 8.98 & 39 & 0.130 & $\begin{array}{l}108.5 \\
(17.1)\end{array}$ & 4 & 0.008 & 5 & 17 & 0.004 & 387 & 11 & 0.007 & 1 \\
\hline $35-39$ & 518900 & 7.49 & 65 & 0.137 & $\begin{array}{l}112.5 \\
(16.2)\end{array}$ & 8 & 0.011 & 9 & 27 & 0.005 & 553 & 17 & 0.010 & 2 \\
\hline $40-44$ & 522574 & 7.49 & 91 & 0.145 & $\begin{array}{l}112.5 \\
(16.2)\end{array}$ & 17 & 0.012 & 17 & 41 & 0.006 & 789 & 26 & 0.011 & 3 \\
\hline $45-49$ & 521716 & 7.49 & 141 & 0.152 & $\begin{array}{l}119.6 \\
(20.1)\end{array}$ & 37 & 0.012 & 28 & 59 & 0.006 & 1146 & 35 & 0.012 & 5 \\
\hline $50-54$ & 502591 & 7.49 & 214 & 0.156 & $\begin{array}{l}119.6 \\
(20.1)\end{array}$ & 68 & 0.011 & 44 & 82 & 0.007 & 1653 & 46 & 0.012 & 7 \\
\hline $55-59$ & 485496 & 5.52 & 311 & 0.164 & $\begin{array}{l}126.8 \\
(19.0)\end{array}$ & 114 & 0.011 & 65 & 112 & 0.007 & 2375 & 57 & 0.013 & 9 \\
\hline $60-64$ & 433268 & 5.52 & 462 & 0.178 & $\begin{array}{l}126.8 \\
(19.0)\end{array}$ & 189 & 0.012 & 97 & 163 & 0.007 & 3300 & 70 & 0.016 & 13 \\
\hline $65-69$ & 392690 & 5.52 & 721 & 0.200 & $\begin{array}{l}133.6 \\
(16.7)\end{array}$ & 294 & 0.013 & 161 & 240 & 0.009 & 4412 & 87 & 0.023 & 21 \\
\hline $70-74$ & 300714 & 5.52 & 1233 & 0.224 & $\begin{array}{l}133.6 \\
(16.7)\end{array}$ & 427 & 0.016 & 250 & 337 & 0.012 & 6132 & 111 & 0.042 & 36 \\
\hline $75-79$ & 229357 & 3.40 & 2242 & 0.249 & $\begin{array}{l}137.9 \\
(14.8)\end{array}$ & 610 & 0.024 & 364 & 460 & 0.020 & 8737 & 153 & 0.103 & 75 \\
\hline $80-84$ & 173515 & 3.40 & 4361 & 0.289 & $\begin{array}{l}137.9 \\
(14.8)\end{array}$ & 889 & 0.040 & 514 & 664 & 0.038 & 12137 & 229 & 0.232 & 153 \\
\hline $85-89$ & 127250 & 3.40 & 8819 & 0.337 & $\begin{array}{l}140.8 \\
(16.2)\end{array}$ & 1396 & 0.081 & 695 & 1085 & 0.073 & 16308 & 368 & 0.446 & 312 \\
\hline $90-94$ & 64694 & 3.40 & 16373 & 0.386 & $\begin{array}{l}140.8 \\
(16.2)\end{array}$ & 2607 & 0.192 & 802 & 1728 & 0.148 & 20097 & 562 & 0.735 & 547 \\
\hline 95-99 & 16786 & 3.40 & 30867 & 0.434 & $\begin{array}{l}140.8 \\
(16.2)\end{array}$ & 3630 & 0.289 & 833 & 2178 & 0.208 & 22859 & 652 & 0.869 & 652 \\
\hline 100-104 & 2018 & 3.40 & 30867 & 0.434 & $\begin{array}{l}140.8 \\
(16.2)\end{array}$ & 3630 & 0.289 & 833 & 2178 & 0.208 & 22859 & 652 & 0.869 & 652 \\
\hline \multicolumn{15}{|c|}{ IR: Incidence Rate; CFR: Case Fatality Rate; DR: Disability rate. } \\
\hline IR, DR an & ortality & e prese & $r 100,0$ & ersons & per pers & & & & & & & & & \\
\hline
\end{tabular}

We estimated that cold eradication generated an additional 1.64 (95\% uncertainty interval (UI): $0.232,4.90)$ undiscounted HALYs per 1000 persons compared with BAU across the lifespan and 0.447 ( $95 \%$ Ul: $0.064,1.34$ ) with a 3 per cent discount applied (Table 3). From the perspective of the 'target population' (i.e. the $5.74 \%$ in cold housing) this equates to 29 undiscounted HALYs per 1000 people (i.e. 1.64/0.0574), or an average (across ages) of one and a half weeks of additional health life per person in cold housing through CVD alone. Eight per cent of this gain is achieved within the first 20 years: we estimated 0.135 (UI: $0.019,0.442$ ) undiscounted HALYs per 1000 persons between 2016 and 2036 . We note that at this point, most cohort members have not reached the ages of high CVD risk. 
Table 3

Future HALYs per people under BAU and HALYs gained by eradication of unhealthy indoor temperature

\begin{tabular}{|c|c|c|c|c|c|c|c|c|c|c|}
\hline & \multirow{2}{*}{\multicolumn{4}{|c|}{$\begin{array}{l}\text { Business as usual } \\
\text { Undiscounted }\end{array}$}} & \multicolumn{6}{|c|}{$\begin{array}{l}\text { Incremental gains in HALYs compared to BAU, for elimination of cold } \\
\text { indoor temperature ( } 95 \% \text { uncertainty interval in parentheses) }\end{array}$} \\
\hline & & & & & \multicolumn{3}{|l|}{ Undiscounted } & \multicolumn{3}{|c|}{ Discounted at $3 \%$} \\
\hline & $\begin{array}{l}\text { Population } \\
\text { in } 2016\end{array}$ & Lifetime & $2016-2025$ & 2016-2035 & Lifetime & $\begin{array}{l}2016- \\
2025\end{array}$ & $\begin{array}{l}2016- \\
2035\end{array}$ & Lifetime & $\begin{array}{l}2016- \\
2025\end{array}$ & $\begin{array}{l}2016- \\
2035\end{array}$ \\
\hline \multirow[t]{2}{*}{ Total } & \multirow[t]{2}{*}{$15,560,018$} & \multirow[t]{2}{*}{$589,561,555$} & \multirow[t]{2}{*}{$128,591,729$} & \multirow[t]{2}{*}{$243,278,999$} & \multirow{2}{*}{$\begin{array}{l}25,500 \\
(3,610 ; \\
76,200)\end{array}$} & 469 & 2,110 & 5,240 & 388 & 1,432 \\
\hline & & & & & & $\begin{array}{l}(67 \\
1480)\end{array}$ & $\begin{array}{l}(302 ; \\
6,560)\end{array}$ & $\begin{array}{l}(995 \\
20,800)\end{array}$ & $\begin{array}{l}(56 ; \\
1220)\end{array}$ & $\begin{array}{l}(206 ; \\
4,460)\end{array}$ \\
\hline \multirow{2}{*}{$\begin{array}{l}\text { Per } 1000 \\
\text { persons }\end{array}$} & & \multirow[t]{2}{*}{37889.52} & \multirow[t]{2}{*}{8264.24} & \multirow[t]{2}{*}{15634.88} & 1.64 & 0.030 & 0.135 & \multirow{2}{*}{$\begin{array}{l}0.447 \\
(0.064 \\
1.34)\end{array}$} & 0.019 & 0.092 \\
\hline & & & & & $(0.232 ; 4.90)$ & $\begin{array}{l}(0.004 \\
0.095)\end{array}$ & $\begin{array}{l}(0.019 \\
0.422)\end{array}$ & & $\begin{array}{l}(0.004 \\
0.079)\end{array}$ & $\begin{array}{l}(0.013 ; \\
0.287)\end{array}$ \\
\hline
\end{tabular}

In Figure 1 we have compared the quantified discounted HALYs gained per 1000 persons with actual CVD interventions in the Australia New Zealand Health Intervention League Table. The hypothetical eradication of indoor cold (HALYs gained during lifetime: 0.447 (Ul: 0.064, 1.34) outperformed many CVD interventions with a lifetime horizon for accrual of health gains. For example, dietary advice for adults $(0.017, \mathrm{Ul}: 0.01,0.027)$, lifestyle program for adults (0.024, UI: 0.01, 0.027) and Community Heart Health Program (0.141, UI: 0.071, 0.221).

\section{Discussion}

This is the first study that quantifies health gains from raising the temperature in Australian cold housing to 20 degrees Celsius, through altering blood pressure and thence cardiovascular disease. These potential health gains are on par with existing lifestyle interventions to reduce CVD risk. The total health gains from lifting indoor air temperatre to a minimum standard will be greater due to additional reduction in respiratory illness and mental ill-health.

While our eradication intervention is hypothetical (and it is assumed perfectly effective, for ever), all other inputs to the model included uncertainty, that was propagated through to uncertainty about the HALY outputs.

The key limitation in this study is its hypothetical nature. This study should be viewed as a departure point for estimating actual interventions (e.g., retrofitting houses), and gives the total CVD envelope of potential health gain by eradicating cold housing. Second, there is 'structural' or mechanistic uncertainty in how changes in temperature flow to changes in blood pressure and then CVD incidence. We started with the effect size of cold onto blood pressure from a well-conducted randomised controlled trial, that examined a short-term effect of temperature change on blood pressure, that is the effect of temperature on labile hypertension (immediate fluctuations in blood pressure) rather than longer-term average blood pressure. By using this effect size in our simulation models, we in turn are assuming that the cumulative impact of labile hypertension has the same impact as a constant but lesser increased in blood pressure (i.e. a cold housing impact of raising systolic blood pressure by $2 \mathrm{~mm} \mathrm{Hg}$ during waking hours whilst in your house in winter is assumed to be similar to a 0.33 (1/6th ) to $0.66(1 / 3 \mathrm{rd}) \mathrm{mmHg}$ increase in blood pressure over the whole year). There is some literature suggesting poor cardiovascular effects of labile hypertension $(19,20)$.

A simulation study forces one to pull together all the data inputs necessary to quantify impacts, and often discloses data weaknesses. In conducting this study, we found that the underlying evidence on the quantitative association of indoor air temperature with health outcomes is lacking (e.g. we could not find robust estimates of cold housing impacts on respiratory disease incidence or severity, restricting us to a focus on blood pressure as a mediating factor to CVD). Also, there is no quality objective data (to our knowledge) on the exact proportion of houses in Australia that have an indoor air temperate in living areas less thnan 18 degrees (and for what duration of the year, and other aspects of exposure characterisaiton). Instead, we had to use subjective measures of indoor temperature from the Australian Housing Conditions Dataset and 'crosswalk' this to being equivalent to the proportion of houses that are cold.

To improve the quality and policy-relevance of this field of research, in addition to improving the quality of input data it is important to quantify the impact of cold housing (and other housing determinants) by socioeconomic position. Inadequate housing is strongly patterned by socioeconomic position (21-24), and provides a domain for intervening to reduce inequalities in health. Next steps include the estimation of cost effectiveness of remedying cold housing through actual interventions, from both a health system and a wider societal perspective given that housing interventions also usually lead to other social impacts such as less energy consumption (see Chapman, Howden-Chapman (25) for an early example). Specific interventions to evaluate include insulation, weatherization (draft-sealing), efficient heating/cooling appliances, cheaper fuel alternatives (solar panels), and subsidy and market-based initiatives to achieve reduction of indoor cold.

\section{Conclusion}

This simulation modelling extends the current knowledge on ill health effects of indoor cold (1). Existing interventional studies from New Zealand also point to cost-effectiveness and equitable health benefits of retrofitting insulation to reduce indoor cold (26). Our study straddles comparative risk assessment and intervention modelling, to create a strong policy argument for addressing indoor temperature. Our finding that that substantial prospective population health 
gains are achievable by eliminating indoor cold in Australia is an important first step in estimating which interventions are the most cost-effective to deliver this. Moreover, this may be as effective in preventing and treating cardiovascular disease as some more medically focussed current approaches.

\section{Abbreviations}

BAU Business as Usual

CVD cardiovascular disease

GBD Global Burden of Disease

HALYs health adjusted life years

PIFs population impact fractions

pMSLT proportional multistate lifetable

RCTs randomised controlled trials

Ul uncertainty intervals

WHO World Health Organisation

YLDs years of life lived with disability

\section{Declarations}

\section{Ethics approval and consent to participate}

Ethics approval for this project not sought as it uses publicly available aggregated data which poses minimal risk for participants.

\section{Consent for publication}

Not applicable

\section{Availability of data and materials}

Data generated or analysed during this study are included in this published article and in its supplementary files. Unit record data from the Australian Housing Conditions Dataset is available from https://dataverse.ada.edu.au/dataset.xhtml?persistentld=doi:10.26193/RDMRD3

\section{Competing interests}

None to declare

\section{Funding}

Project funded by Affordable Housing Hallmark Initiative seed funding by University of Melbourne.

\section{Acknowledgements}

We are grateful to Shiva Raj Mishra for his comments on our manuscript

\section{References}

1. WHO. Housing and health guidelines. Geneva: World Health Organization; 2018. Report No.: CC BY-NC-SA 3.0 IGO.

2. Daniel L, Baker E, Beer A, Pham NTA. Cold housing: evidence, risk and vulnerability. Housing Studies. 2021;36(1):110-30.

3. Daniel L, Baker E, Williamson T. Cold housing in mild-climate countries: A study of indoor environmental quality and comfort preferences in homes, Adelaide, Australia. Building and Environment. 2019;151

4. Saeki K, Obayashi K, Iwamoto J, Tanaka Y, Tanaka N, Takata S, et al. Influence of room heating on ambulatory blood pressure in winter: a randomised controlled study. J Epidemiol Community Health. 2013;67(6):484-90.

5. Saeki K, Obayashi K, Iwamoto J, Tanaka Y, Tanaka N, Takata S, et al. Influence of room heating on ambulatory blood pressure in winter: a randomised controlled study. J Epidemiol Community Health. 2013;67(6):484-90.

6. Barnett AG, Sans S, Salomaa V, Kuulasmaa K, Dobson AJ, Project ftWM. The effect of temperature on systolic blood pressure. 2007;12(3):195-203.

7. Saeki K, Obayashi K, Iwamoto J, Tone N, Okamoto N, Tomioka K, et al. The relationship between indoor, outdoor and ambient temperatures and morning BP surges from inter-seasonally repeated measurements. Journal of human hypertension. 2014;28(8):482-8. 
8. Shiue I, Shiue M. Indoor temperature below $18 \mathrm{C}$ accounts for $9 \%$ population attributable risk for high blood pressure in Scotland. International journal of cardiology. 2014;171(1):e1-e2.

9. Blakely T, Moss R, Collins J, Mizdrak A, Singh A, Carvalho N, et al. Proportional multistate lifetable modelling of preventive interventions: concepts, code and worked examples. International Journal of Epidemiology. 2020.

10. Briggs AD, Wolstenholme J, Blakely T, Scarborough P. Choosing an epidemiological model structure for the economic evaluation of non-communicable disease public health interventions. Population health metrics. 2016;14(1):17.

11. Blakely T, Moss R, Collins J, Mizdrak A, Singh A, Carvalho N, et al. Proportional multistate lifetable modelling of preventive interventions: concepts, code and worked examples. International journal of epidemiology. 2020;49(5):1624-36.

12. University of Otago UoM. ANZ-HILT: Australia and New Zealand Health Intervention League Table (Version 2.0) 2019 [Available from: https://www.otago.ac.nz/wellington/departments/publichealth/research/bode3/otago693006.html.

13. Stevens SL, Wood S, Koshiaris C, Law K, Glasziou P, Stevens RJ, et al. Blood pressure variability and cardiovascular disease: systematic review and meta-analysis. Bmj. 2016;354:i4098.

14. Baker E, Daniel L, Bentley R, Pawson H, Stone W, Rajagopalan P, et al. The Australian housing conditions dataset-technical report. 2018.

15. The Australian Housing Conditions Dataset [Internet]. ADA Dataverse. 2019. Available from: http://dx.doi.org/10.26193/RDMRD3.

16. Barendregt JJ, Van Oortmarssen GJ, Vos T, Murray CJ. A generic model for the assessment of disease epidemiology: the computational basis of DisMod II. Popul Health Metr. 2003;1(1):4.

17. Australian Bureau of Meteorology. Australian climate variability \& change - Time series graphs [Internet]. Canberra: Australian Bureau of Meteorology; 2016 [updated c2021; cited 2021 Sept 16]. Available from:

http://www.bom.gov.au/climate/change/\#tabs=Tracker\&tracker=timeseries\&tQ=graph\%3Dtmean\%26area\%3Dwa\%26season\%3D0112\%26ave_yr\%3DT.

18. Forouzanfar MH, Liu P, Roth GA, Ng M, Biryukov S, Marczak L, et al. Global Burden of Hypertension and Systolic Blood Pressure of at Least 110 to 115 mm Hg, 1990-2015. JAMA. 2017;317(2):165-82.

19. Sanidas E, Grassos C, Papadopoulos DP, Velliou M, Tsioufis K, Mantzourani M, et al. Labile hypertension: a new disease or a variability phenomenon? Journal of Human Hypertension. 2019;33(6):436-43.

20. Mann SJ. The Clinical Spectrum of Labile Hypertension: A Management Dilemma. The Journal of Clinical Hypertension. 2009;11(9):491-7.

21. Baker E, Bentley R, Lester L, Beer A. Housing affordability and residential mobility as drivers of locational inequality. Applied Geography. 2016;72:65-75.

22. Bentley RJ, Pevalin D, Baker E, Mason K, Reeves A, Beer A. Housing affordability, tenure and mental health in Australia and the United Kingdom: a comparative panel analysis. Housing Studies. 2016;31(2):208-22

23. Kavanagh AM, Aitken Z, Baker E, LaMontagne AD, Milner A, Bentley R. Housing tenure and affordability and mental health following disability acquisition in adulthood. Soc Sci Med. 2016;151:225-32.

24. Pevalin DJ, Reeves A, Baker E, Bentley R. The impact of persistent poor housing conditions on mental health: A longitudinal population-based study. Preventive medicine. 2017;105:304-10.

25. Chapman R, Howden-Chapman P, Viggers H, O'Dea D, Kennedy M. Retrofitting houses with insulation: a cost-benefit analysis of a randomised community trial. Journal of epidemiology and community health. 2009;63(4):271-7.

26. Howden-Chapman P, Crane J, Matheson A, Viggers H, Cunningham M, Blakely T, et al. Retrofitting houses with insulation to reduce health inequalities: aims and methods of a clustered, randomised community-based trial. Soc Sci Med. 2005;61(12):2600-10.

27. Global Burden of Disease Study 2017 (GBD 2017) Results. [Internet]. Seattle, United States: Institute for Health Metrics and Evaluation (IHME). 2018. Available from: http://ghdx.healthdata.org/gbd-results-tool.

28. Barendregt JJ, Van Oortmarssen GJ, Vos T, Murray CJ. A generic model for the assessment of disease epidemiology: the computational basis of DisMod II. Population health metrics. 2003;1(1):1-8.

29. Australian Bureau of Statistics. National Health Survey: First results, 2017-18.. 2018.

30. Vos T, Carter R, Barendregt J, Mihalopoulis C, Veerman L, Magnus A, et al. Assessing Cost-Effectiveness in the Prevention (Ace-Prevention): Final Report. Brisbane and Melbourne: University of Queensland and Deakin University; 2010 September 2010.

\section{Figures}




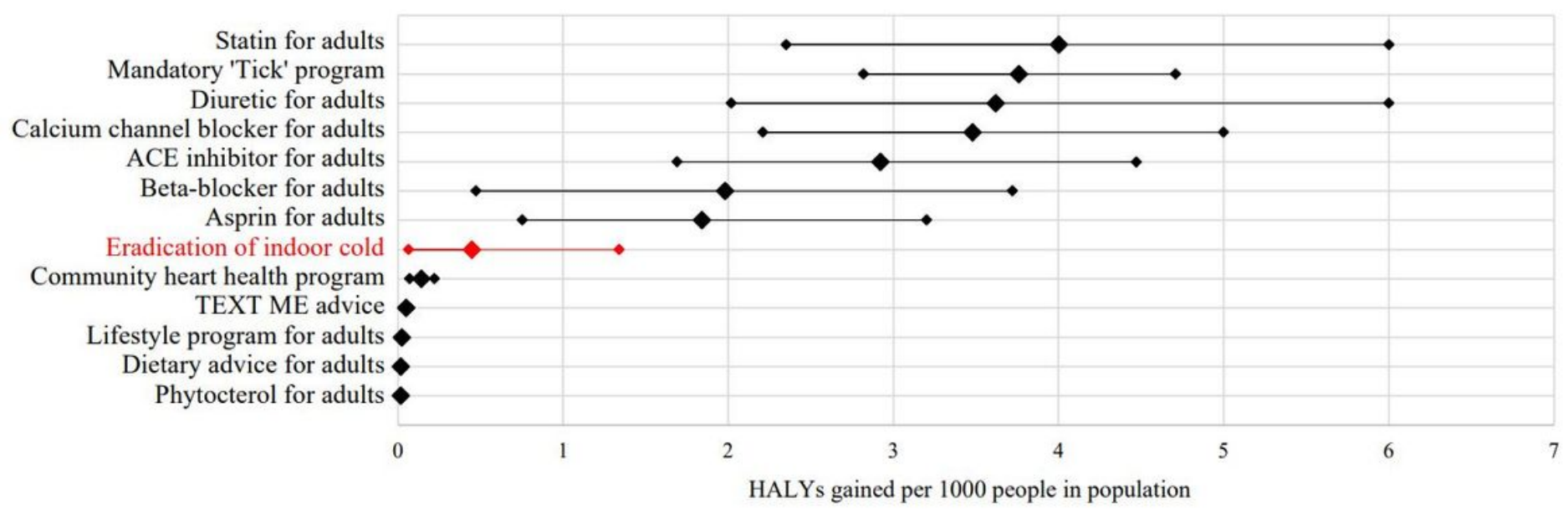

Figure 1

Ranking of eradicating exposure to indoor cold compared to actual preventive interventions

Note: All interventions in adults aged 35-84 years old with lifetime duration unless otherwise stated in the footnotes. Standard dose of statin for adults with $5-9 \%$ five-year risk of CVD through primary care practice. Mandataory 'Tick' program to reduce salt in bread, margarine and breakfast cereal by 10.65 mgNa day for men and $7.3 \mathrm{mgNa}$ for women with at least $5 \%$ five-year risk of CVD. Standard dose of diuretic for adults with 5-9\% five-year risk of CVD through primary care practice. Standard dose of calcium channel blocker for adults with 5-9\% five-year risk of CVD through primary care practice. Standard dose of ACE inhibitor for adults with 10-14\% five-year of CVD risk through primary care practice. Standard dose of beta-blocker for adults with 5-9\% five-year CVD risk through primary care practice. Standard dose of aspirin for adults with 5-9\% five-year risk of CVD through a combination of primary care practice prescription (50\%) and over the counter (50\%) use. Community heart health program to promote dietary change, physical activity and smoking cessation for the whole population. Tobacco, Exercise and Diet Messages (TEXT ME) providing advice, motivation, information and support to improve health related behaviours plus usual care, for individuals with documented CHD over a lifetime. Lifestyle program providing professional advice in diet and physical activity for adults with 5-9\% five-year risk of CVD. Dietary advice for adults with 5-9\% five-year CVD risk. Phytosterol hytosterol-enriched margarine (92 grams per $\mathrm{kg}$ of margarine) for adults with 5-9\% five-year risk of CVD(30)

\section{Supplementary Files}

This is a list of supplementary files associated with this preprint. Click to download.

- Supplementaryfile.docx 